\title{
殺ダニ剂エトキサゾールの開発
}

鈴木純二, 石田達也, 渋谷一郎, 戸田和哉

八洲化学工業株式会社研究所

\section{Development of a New Acaricide, Etoxazole}

\author{
Junji SuzuKI, Tatsuya IshidA, Ichiro SHIBuYA and Kazuya TodA \\ Agro-Science Research Institute, Yashima Chemical Industry Co., Ltd., 173-2, Guze, Tomitake, \\ Nagano 381-0006, Japan
}

\section{はじめに}

エトキサゾール (etoxazole) は, 八洲化学工業（株）が 開発した新しい殺ダニ剤である.

果樹，野菜，茶などを加害するハダ二類は，一般に薬剤 に対する抵抗性を発達させやすいことから殺ダニ剂の寿命 は短く，農薬市場においては絶えず新しい構造・骨格で新 しい作用を持つ殺ダニ剂が望まれている. 1980 年代半ばに 開発された2-チアゾリドン環を有するへキシチアゾクス は,八ダ二類に対して強い殺卵作用と生育調節作用を示し, 主要な殺ダニ剤の地位を占めた ${ }^{1)}$. その後, 1990 年代に日本 で農薬登録された合成殺虫・殺ダ二剂は 35 剂あり，このj ち 14 剂もが殺ダニ剤で，神経や呼吸系に作用する剂が多 かった ${ }^{2,3)}$. 最近ではフェニルウラシルの誘導体が, 様々な ダニ類に対して強力な殺ダ二効果と殺虫効果を示すことが 報告されており，殺虫・殺名二剂の開発は活発である ${ }^{4}$.

筆者らは, 新農薬の創製を目的とした化合物を合成・検索 するにあたり，キノコの生理活性物質に着目し，その構造を リード化合物として活用することを試みた。エトキサゾー ルの 1,3-オキサゾリン骨格は，八エトリシメジやイボテン グダケなどから抽出・単離された殺虫活性を有するトリコ ロミン酸やイボテン酸 $5-7)$ および殺虫, 殺ダニ活性を示す 置換ベンゼン環を持つ 1,2,4-オキサジアゾールや1,3-オキ サゾール-5-オン 8 ,9) などを基にデザインしたものである.

1987 年，リード化合物として 2-フェニル-1,3-オキサゾ リン誘導体の合成展開を始め, 1990 年にエトキサゾールを 殺ダニ剂として開発候補化合物に選抜した。1992 年には試 験番号 YI-5301SC として日本植物防疫協会での委託試験 や各種の毒性および代謝試験を開始し，1998 年 4 月 24 日 に農薬登録を取得し商品名バロックフロアブルとして上市 した。
本報では，エトキサゾール並びにその類縁化合物の合成 および生物活性について紹介するとともに，環境中での挙 動についても得られた知見を報告する。

\section{発見の経 緯}

\section{1. 背景およびリード化合物}

1,3-オキサゾリンの誘導体は，農業分野ではあまり利用 されていないが，天然物では，1986 年にある種の放線菌の 代謝産物中に見いだされたキチナ一ゼ阻害物質のアロサミ ジンは，2-アミノ-1,3-オキサゾリン構造を部分的に含 み ${ }^{10)}$ ，また，合成化合物では，2-アミノ-1,3-オキサゾリン の誘導体に，ダニやアブラムシに対して殺虫活性を有する という報告がある ${ }^{11}$.

筆者らは, 1980 年の中頃，除草剤を目的とした置換つェ

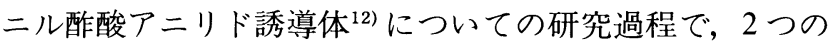
ベンゼン環の置換基の位置と種類によってイエバエやコナ ガなどに対して殺虫活性を示す化合物を見い出した。 しか し，置換基の種類や位置について種々の組み合わせを検討 したが，より高い活性化合物を得ることはできなかった。 そこで，これを発展させる方向として，既述の天然物や既 知の活性化合物の構造を基に 2 つの置換ベンゼン環に挾ま れた窒素, 酸素原子を含む複素 5 員環化合物をデザインし た(Fig. 1). 当初デザインしたイソオキサゾールの誘導体よ りは，フェニルアラニノールと安息香酸から簡便に合成で きるオキサゾリン誘導体を最初に合成したところ，4-ベン ジル-2-フェニル-1,3-オキサゾリンが，十ミハダニの卵に 対して高い殺卵活性を示し，コナが等にも弱いながら殺虫 活性を示した。さらなる活性の向上を目指して周辺化合物 を合成・評価した結果，2,4-ジフェニル-1,3-オキサゾリン 誘導体が，十ミハダニの卵および幼若虫に対して強い殺卵 活性と脱皮阻害活性を持つことを見いだし，これをリード 


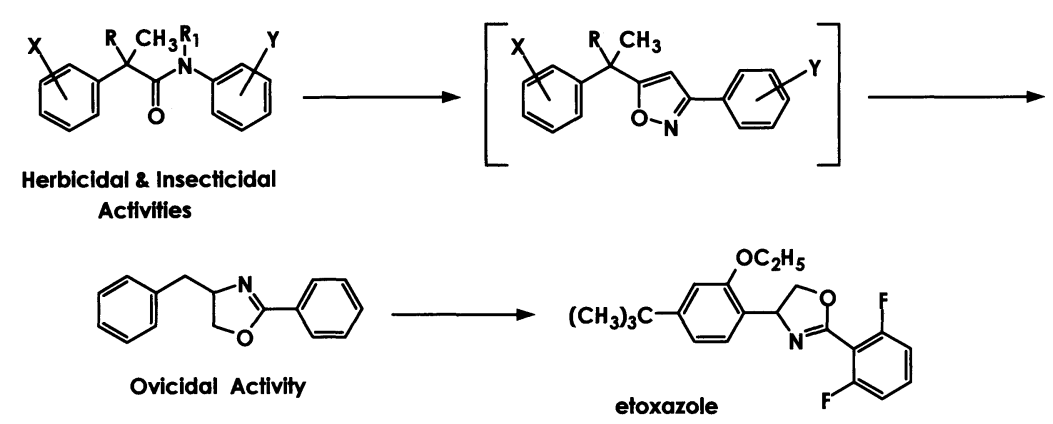

Fig. 1 Lead compounds for etoxazole.

Table 1 Ovicidal and insecticidal activities of 2-substituted phenyl-4-phenyl-1,3-oxazolines.

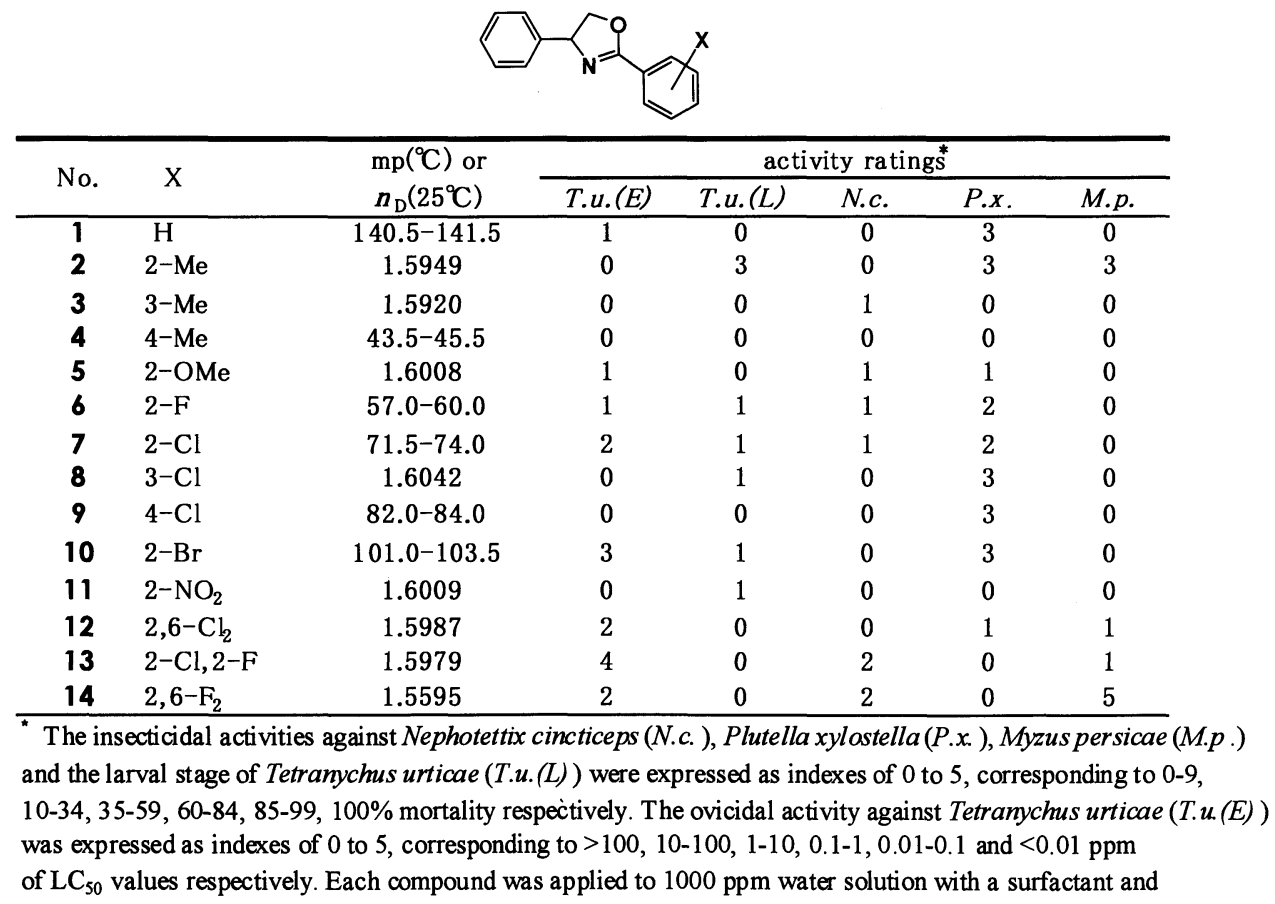

化合物として置換基の最適化を行った。

\section{2. リード化合物の展開}

2,4-ジフェニル-1,3-オキサゾリン（1）は，4-ベンジル2-フェニル-1,3-オキサゾリンよりもナミハダニに対する 殺卵活性が強かった。そこで，2,4-ジフェニル-1,3-オキサ ゾリンについて 2 つのベンゼン環の置換基とその位置およ びオキサゾリンに替わる窒素および酸素原子を含む複素 5 員環の検討を行った。

2 位ベンゼン環の置換基がオルト位にあるとき, 他の置 換位置にあるときよりも強い殺卵活性を示した（Table 1). 置換基の種類では，八ロゲン原子が良く，臭素である化合 物 10 のナミハダニ卵に対する $\mathrm{LC}_{50}$ 值は $0.1 \sim 1 \mathrm{ppm}$ で, 無
置換である化合物 1 の 100 倍高かった，検討した中では， オルト位にフッ素と塩素原子が 2 置換した化合物 13 が最 も強い殺卵活性を示した。フッ素原子が 2 置換した化合物 14 は, 化合物 13 よりも殺卵活性は劣ったが, モモアカアブ ラムシの幼虫に対しては高い殺虫活性を示した.

次に, 4 位ベンゼン環の置換基では, Table 2 に示す通り, パラ位の塩素原子やアルキル基および長いアルコキシ基 は，ナミ八ダ二に対する殺卵活性を高めた。しかし，親水 性の水酸基（31） やジメチルアミ/基（32）などは，無置 換(14)よりも劣った. エチル基(25)，イソプロピル基(26), ブチル基 $(27,28)$ ，オクチル基（29）は，ナミハダニの卵 に対して LC L $_{50}$ 值が $0.01 \mathrm{ppm}$ 以下の非常に強い殺卵活性を 示し，モモアカアブラムシの幼虫に対する殺虫活性も高 
Table 2 Ovicidal and insecticidal activities of 2,6-difluorophenyl-4-substituted phenyl-1,3-oxazolines.

\begin{tabular}{|c|c|c|c|c|c|c|}
\hline \multirow{2}{*}{ No. } & \multirow{2}{*}{$\mathrm{Y}$} & \multirow{2}{*}{$\begin{array}{c}\mathrm{mp}\left({ }^{\circ} \mathrm{C}\right) \text { or } \\
n_{\mathrm{D}}\left(25^{\circ} \mathrm{C}\right)\end{array}$} & \multicolumn{4}{|c|}{ activity ratings ${ }^{*}$} \\
\hline & & & T.u.(E) & N.c. & P.x. & M.p. \\
\hline 14 & $\mathrm{H}$ & 1.5595 & 2 & 2 & 0 & 5 \\
\hline 15 & $2-\mathrm{Cl}$ & $62.5-63.5$ & 3 & 4 & 2 & 5 \\
\hline 16 & $3-\mathrm{Cl}$ & 1.5674 & 2 & 0 & 0 & 0 \\
\hline 17 & $4-\mathrm{Cl}$ & 1.5701 & 5 & 3 & 0 & 0 \\
\hline 18 & $2-\mathrm{OMe}$ & $62.5-63.5$ & 1 & 1 & 0 & 0 \\
\hline 19 & 3-OMe & 1.5610 & 2 & 0 & 0 & 0 \\
\hline 20 & 4-OMe & $131.5-133.0$ & 2 & 1 & 0 & 4 \\
\hline 21 & 4-SMe & 1.5988 & 3 & 0 & 0 & 5 \\
\hline 22 & $2-\mathrm{Me}$ & 1.5556 & 1 & 1 & 0 & 0 \\
\hline 23 & $3-\mathrm{Me}$ & 1.5575 & 1 & 0 & 0 & 0 \\
\hline 24 & 4-Me & 1.5552 & 3 & 3 & 0 & 5 \\
\hline 25 & $4-E t$ & 1.5576 & 5 & 3 & 0 & 5 \\
\hline 26 & 4-iPr & 1.5512 & 5 & 3 & 0 & 5 \\
\hline 27 & $4-\mathrm{nBu}$ & $102.5-105.5$ & 5 & 1 & 0 & 5 \\
\hline 28 & $4-\mathrm{tBu}$ & 1.5471 & 5 & 3 & 0 & 5 \\
\hline 29 & $4-\mathrm{nC}_{8} \mathrm{H}_{17}$ & 1.5226 & 5 & 0 & 4 & 5 \\
\hline 30 & $4-\mathrm{O}-\mathrm{nC}_{8} \mathrm{H}_{17}$ & 1.5284 & 5 & 0 & 3 & 4 \\
\hline 31 & $4-\mathrm{OH}$ & $152.0-153.0$ & 1 & 3 & 1 & 0 \\
\hline 32 & $4-\mathrm{N}\left(\mathrm{Me}_{2}\right.$ & semi-solid & 1 & 0 & 0 & 4 \\
\hline
\end{tabular}

*Abbreviations, see Table 1

Table 3 Ovicidal and insecticidal activities of 2,6-difluorophenyl-4-(4-tert-butyl-2-substituted phenyl)-1,3-oxazolines.

\begin{tabular}{|c|c|c|c|c|c|c|c|}
\hline \multirow{2}{*}{ No. } & \multirow{2}{*}{$\mathrm{Y}_{1}$} & \multirow{2}{*}{$\begin{array}{c}\mathrm{mp}\left({ }^{\circ} \mathrm{C}\right) \text { or } \\
n_{\mathrm{D}}\left(25^{\circ} \mathrm{C}\right)\end{array}$} & \multicolumn{2}{|c|}{ ovicidal activity(\%) } & \multicolumn{3}{|c|}{ activity ratings } \\
\hline & & & P.c. $(100 \mathrm{ppm})$ & T.k. (10ppm) & N.c. & P.X. & M.p. \\
\hline 28 & $\mathrm{H}$ & 1.5471 & 100.0 & 100.0 & 3 & 0 & 5 \\
\hline 33 & $2-\mathrm{Cl}$ & 1.5560 & 39.1 & 100.0 & 5 & 1 & 5 \\
\hline 34 & $2-\mathrm{OMe}$ & $76.0-77.5$ & 100.0 & 91.4 & 2 & 4 & 5 \\
\hline 35 & $2-\mathrm{OEt}$ & $101.0-102.0$ & 100.0 & 91.7 & 5 & 5 & 5 \\
\hline 36 & $2-\mathrm{O}-\mathrm{nPr}$ & 1.5349 & 100.0 & 75.4 & 3 & 4 & 5 \\
\hline 37 & $2-\mathrm{O}-\mathrm{nBu}$ & 1.5316 & 99.0 & 99.0 & 0 & 2 & 5 \\
\hline 38 & $2-\mathrm{Me}$ & 1.5476 & 82.4 & 100.0 & 5 & 0 & 5 \\
\hline 39 & $2-\mathrm{Et}$ & 1.5399 & 23.8 & 100.0 & 0 & 0 & 5 \\
\hline 40 & $2-\mathrm{nPr}$ & 1.5387 & 100.0 & 39.7 & 0 & 3 & 3 \\
\hline
\end{tabular}

"Abbreviations, see Table 1; P.c. and T.k. stand for Panonychus citri and Tetranychus kanzawai respectively.

かった。

高活性化合物の中から開発候補化合物を選抜するに際し て，既存の薬剂と交差抵抗性を示す化合物を回避する目的 で,これまで行っていた感受性の十ミハダニでの検定から， 当時，八ダニ防除剂として主に使われていたへキシチアゾ クスに低感受性のミカンハダニやカンザワハダニを用いた 検定に変更した．その結果, Table 3 に示す通り，オルト位 の置換基の種類によって，ミカンハダニやカンザワハダニ およびコナガやツマグロヨコバイに対する活性に強弱が認 められた.ミカンハダニとカンザワハダニの卵に対して高 い殺畉活性を示した化合物は，オルト位に置換基のない化
合物 28 とメトキシ基 (34)，エトキシ基 (35)，ブトキシ基 (37) であった，化合物 35 (エトキサゾール) は，コナガ, ツマグロヨコバイおよびモモアカアブラムシに対しても高 い殺虫活性を示した。

一方, 複素環に関して, 1,3-オキサゾリン環と 1,3-オキサ ゾール環および 1,3-チアゾリン環との比較や複素環上での フェニル基の置換位置について検討した.その結果を Table 4 に示した. 1,3-オキサゾリン環は，1,3-オキサゾー ル環や1,3-チアゾリン環よりも優れ，フェニル基の置換位 置は, 2,4 置換が 2,5 置換よりも良いことが判った。 
Table 4 Heterocyclic analogues of 2,6-difluorophenyl-4-phenyl-1,3-oxazoline and their ovicidal and insecticidal activities.

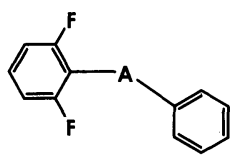

\begin{tabular}{|c|c|c|c|c|c|c|c|}
\hline \multirow{2}{*}{ No } & \multirow{2}{*}{ A } & \multirow{2}{*}{$\begin{array}{l}\mathrm{mp}\left({ }^{\circ} \mathrm{C}\right) \text { or } \\
n_{\mathrm{D}}\left(25^{\circ} \mathrm{C}\right)\end{array}$} & \multicolumn{5}{|c|}{ activity ratings } \\
\hline & & & T.u.(E) & T.u. $(L)$ & N.c. & P.x. & M.p. \\
\hline 14 & & 1.5595 & 2 & 2 & 0 & 5 & 0 \\
\hline 41 & & 1.5627 & 2 & 1 & 2 & 4 & 0 \\
\hline 42 & & 1.5522 & 0 & 0 & 0 & 0 & 0 \\
\hline 43 & & $47.0-47.5$ & 0 & 1 & 0 & 0 & 0 \\
\hline 44 & & $93.0-94.0$ & 0 & 0 & 0 & 0 & 0 \\
\hline 45 & & $64.0-66.5$ & 1 & 0 & 0 & 0 & 0 \\
\hline 46 & & $55.0-57.0$ & 0 & 0 & 0 & 0 & 0 \\
\hline
\end{tabular}

*Abbreviation, see in Table 1.

\section{名称および性状}

一般名：エトキサゾール (etoxazole)

商品名：バロックフロアブル, ビルク水和剤

化学名：(RS)-5-tert-ブチル-2-[2-(2,6-ジフルオロフェ ニル)-4,5-ジヒドロ-1,3-オキサゾール-4-イル] フェネトール

$(R S)$-5-tert-butyl-2-[2-(2,6-difluorophenyl) -4,5dihydro-1,3-oxazol-4-yl] phenetole

分子式： $\mathrm{C}_{21} \mathrm{H}_{23} \mathrm{~F}_{2} \mathrm{NO}_{2}$

分子量：359.4

外 観：白色細粒

融 点：101 $102^{\circ} \mathrm{C}$

溶解度 $\left(\mathrm{g} / l: 20^{\circ} \mathrm{C}\right):$ 水 : $7.54 \times 10^{-5}$, アセトン : 300 , ジク ロロメタン：1050, 酢酸エチル：250, メタノー ル：90, ヘキサン：13

蒸気圧： $2.18 \times 10^{-6} \mathrm{~Pa}\left(25^{\circ} \mathrm{C}\right)$

分配係数 $\left(n-\right.$ オクタノール/水) $: \log P_{\mathrm{ow}}=5.59\left(25^{\circ} \mathrm{C}\right)$

\section{I業 化}

エトキサゾールは，2つの置換ベンゼン環と 1,3-オキサ ゾリン環の 3 つの環より構成されており，原体合成に際し ては，1,3-オキサゾリン環の構築がポイントであった. 1,3オキサゾリン誘導体は，一般的には，カルボン酸類とアミ ノエタノール誘導体とでカルボン酸アミド誘導体とし，こ
れを脱水剤または水酸基をハロゲン化した後のアルカリ処 理で環化することによって合成される，エトキサゾールの 原体合成は，アミノエタノール誘導体を用いることなく， 少ない工程数でカルボン酸アミド誘導体を合成することに よって工業化に成功した．概略を Fig. 2 に記す。

先ず，2,6-ジフルオロベンズアミドとクロロアセトアル デヒドジメチルアセタールより N-(2-クロロ-1-メトキシ エチル)-2,6-ジフルオロベンズアミド (amidacetal) を合成 し，これと 3-tert-ブチルフェネトール (MTBPE) で塩化ア ルミニウムを用いた Friedel-Crafts 反応によって N-[1(4-tert-ブチル-2-エトキシフェニル)-2-クロロエチル]2,6-ジフルオロベンズアミド (chloroamide) を合成する. 最後は, chloroamideを水酸化ナトリウムで環化すること により，エトキサゾールを高収率で合成することができ $ろ^{13,14)}$.

\section{エトキサゾールの特性}

\section{1. 基碟活性}

初期段階のスクリーニングでは，高濃度の試験であるた め，コナガやッマグロヨコバイなどに対しても比較的高い 殺虫活性を示したが，実用的な効果は期待できない，しか し，八ダニ類の卵や幼虫およびアブラムシ類の若虫には極 めて低濃度で強力な活性を示した。野菜，果樹および茶な どを加害する重要なハダ二類に対する殺卵活性を Table 5 に示した。十ミハダニ，カンザワハダニ，ミカンハダニお 


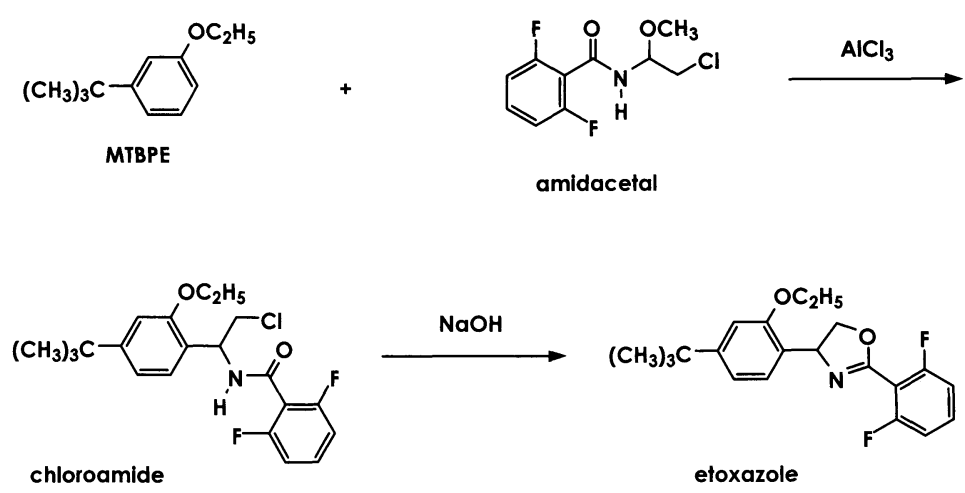

Fig. 2 Synthetic route of etoxazole.

Table 5 Ovicidal activity of etoxazole against four major mites. ${ }^{a)}$

\begin{tabular}{ccccc}
\hline \multirow{2}{*}{ miticides } & \multicolumn{4}{c}{$\mathrm{LC}_{50}$ (mg a.i./1) } \\
\cline { 2 - 5 } & T.u. & T.k. & P.c. & P.u. \\
\hline etoxazole & 0.003 & 0.005 & 0.001 & 0.002 \\
hexythiazox & 0.8 & 0.9 & 0.4 & 0.6 \\
\hline a) leaf-disc dipping method (rather late stage of eggs), \\
T.u. : Tetranychus urticae, T.k. : Tetranychus kanzawai, \\
P.c .: Panonychus citri, P.u.: Panonychus ulmi
\end{tabular}

Table 6 Ovicidal activity of etoxazole and well known miticides at different stage of eggs. ${ }^{\text {b) }}$

\begin{tabular}{|c|c|c|c|c|c|c|}
\hline \multirow{3}{*}{ miticides } & \multicolumn{6}{|c|}{$\mathrm{LC}_{50}$ (mg a.i./1) } \\
\hline & \multicolumn{4}{|c|}{ Tetranychus urticae } & \multicolumn{2}{|c|}{ Panonychus citri } \\
\hline & $2-24 \mathrm{~h}$ & $24-48 \mathrm{~h}$ & $48-72 \mathrm{~h}$ & $72-96 \mathrm{~h}$ & $0-48 \mathrm{~h}$ & $120-168 \mathrm{~h}$ \\
\hline etoxazole & $<0.048$ & $\begin{array}{c}0.048^{-} \\
0.19\end{array}$ & $\begin{array}{c}0.048^{-} \\
0.19\end{array}$ & $\begin{array}{c}0.048^{-} \\
0.19\end{array}$ & 0.23 & $>12.5$ \\
\hline hexythiazox & $<0.78$ & $<0.78$ & 0.67 & 2.10 & 5.40 & $>12.5$ \\
\hline clofentezine & 1.8 & 3.7 & 14.1 & 17.8 & $>50.0$ & $>50.0$ \\
\hline pyridaben & - & - & - & - & 1.80 & $>12.5$ \\
\hline
\end{tabular}

${ }^{\text {b) }}$ leaf-disc dipping method
Table 7 Acaricidal activities of etoxazole against different stages of mites. ${ }^{\text {b) }}$

\begin{tabular}{lccccc}
\hline \multirow{2}{*}{ stage } & \multicolumn{4}{c}{$\mathrm{LC}_{50}$ (mg a.i./l) } \\
\cline { 2 - 3 } & \multicolumn{2}{c}{ Tetranychus } & kanzawai & & \multicolumn{2}{c}{ Panonychus citri } \\
\cline { 2 - 3 } \cline { 5 - 6 } & susceptible & resistant & & susceptible & resistant \\
\hline eggs & 0.005 & 0.05 & & 0.001 & 0.5 \\
larvae & 0.001 & $<0.001$ & & $<0.001$ & 0.08 \\
protonymphs & $<0.001$ & $<0.001$ & & $<0.001$ & 0.08 \\
deutonymphs & $<0.001$ & $<0.001$ & & $<0.001$ & 0.08 \\
adults & $>1000$ & $>1000$ & & $>1000$ & $>1000$ \\
\hline
\end{tabular}

b) leaf-disc dipping method

よびリンゴハダニに対するリーフデイスク浸漬法での $\mathrm{LC}_{50}$ 值は $0.001 \sim 0.005 \mathrm{ppm}$ で，対照に用いた薬剤より 100 倍程度強い, スペクトラムの広い殺多二剂であることがわ かった，次に，産下された卵のステージによって効果に差 があるかどうかをナミハダニとミカンハダニを用いて調べ た結果が，Table 6 である.十ミハダニでは，産下後 96 時 間の卵に対しても低い濃度で殺卵効果を示した。ミカン八 ダニでは, 産下後 48 時間の卵に対しては, 同時に試験した 他の薬剤よりも低い濃度で効果を示した。 また，八夕゙ニの 発育ステージのどの部分に作用を示すかをカンザワハダニ とミカンハダニを用いてリーフディスク浸漬法で検討した 結果を Table 7 に示した. 卵, 幼虫, 第 1 若虫および第 2 若 虫のいずれに対しても低い濃度で優れた効果を示したが, 成虫に対しては, 1000 ppm でも殺虫効果を示さなかった.
Table 8 Insecticidal activity of etoxazole and some kinds of insecticides against nymphal stage of aphids. ${ }^{\text {c) }}$

\begin{tabular}{lccccc}
\hline \multirow{2}{*}{ aphidicide } & \multicolumn{4}{c}{$\mathrm{LC}_{50}(\mathrm{mg}$ a.i./1) } \\
\cline { 2 - 3 } & \multicolumn{2}{c}{ Myzus persicae } & & \multicolumn{2}{c}{ Aphis gossypii } \\
\cline { 2 - 3 } \cline { 5 - 6 } & susceptible & resistant & & susceptible & resistant \\
\hline etoxazole & 1.2 & 2.1 & & 0.5 & 0.8 \\
permethrin & 11.4 & 45.1 & & 0.5 & 2115 \\
acephate & 21.6 & 257 & & 11.0 & 216 \\
carbaryl & 78.9 & 346 & & 4.5 & 26.2 \\
flufenoxuron & $>200$ & $>200$ & & $>200$ & $>200$ \\
\hline
\end{tabular}

c) leaf dipping method

モモアカアブラムシとワタアブラムシに対する効果を リーフ浸漬法で検討した結果，両方の幼虫に対して比較に 用いた他の薬剤よりも低い濃度で殺虫活性を示し，かつ， 抵抗性を有するアブラムシにも有効であった（Table 8). エトキサゾールは，八ダニ類に対してへキシチアゾクス やクロフェンテジンなどと同様な脱皮阻害作用を示すが， アブラムシなどにも同じような作用を示す点が異なる ${ }^{15)}$. アブラムシに対しては，直接の殺成虫効果は認められない が, 処理虫は産仔が阻害される. ワタアブラムシでは, 産 仔が停止した後に成虫の体が萎縮して最終的に死亡し た ${ }^{16)}$.このようなアブラムシに対する IGR 様な作用は，こ れまでに知られておらず17)，これがエトキサゾールの特徴 的な作用の一つである. 


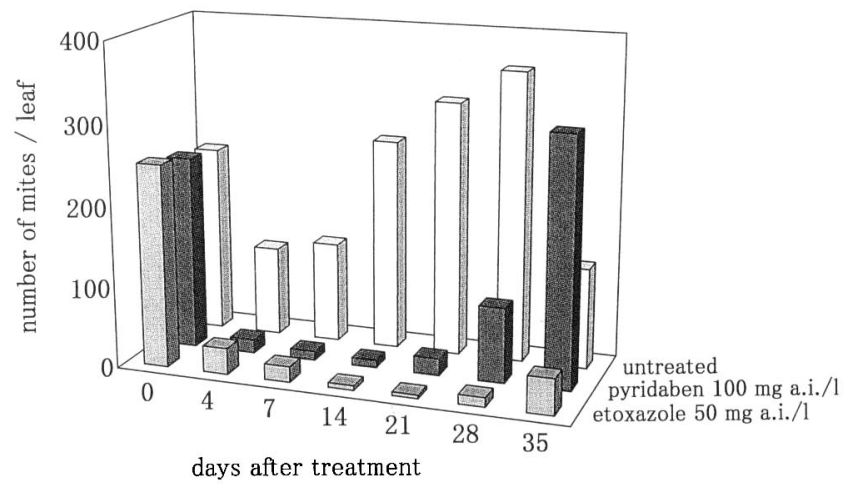

Fig. 3 Suppressive efficacy of etoxazole against T. urticae on apples in field trials (1991).

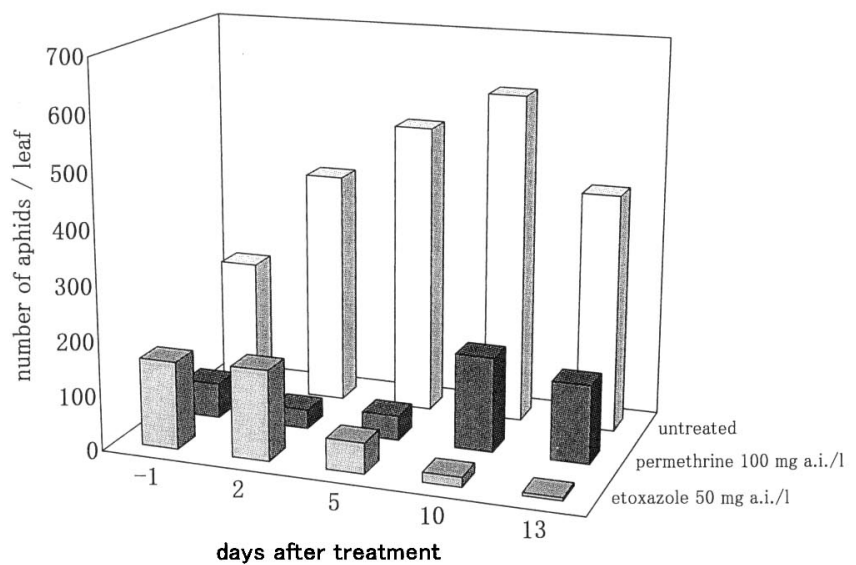

Fig. 4 Suppressive efficacy of etoxazole against $A$. gossypii on cucumbers in field trials (1992).

\section{2. 固場試験}

エトキサゾールは, 既述の通り IGR 様の殺ダニ作用を示 し，殺卵・殺幼若虫活性はあるが，成虫には効かないため 遅効的である反面，残効性に優れている。クんごの十ミ八 ダニに対する圃場試験の結果を Fig. 3 に示した。困から明 らかなように1か月以上ダ二の密度を低く抑えた。また， きゅうりのワタアブラムシに対する固場試験では，Fig. 4 に示すとおり，即効性はないものの長い間アブラムシの密 度を抑制した。

\section{安全 性}

\section{1. 人畜毒性と有用生物への影響}

エトキサゾールの原体および $10 \%$ ワロアブルは，ラット およびマウスに対する急性毒性は低く，いわゆる普通物に 該当する。目および皮膚に対する一次刺激性，皮䖉に対市 る感作性では，10\%フロアブルで目に対して極軽度の刺激 性が認められたのみである。

ラット，マウスおよびイヌを用いた亜急性および慢性毒 性, 発ガン性試験では, 肝の臓器重量の増加, 腫大, 小葉
中心性肝細胞肥大およびこれらを反映する血液生化学的測 定項目の変動が認められたが，いずれの動物種においても 催腫瘍性は認められなかった。また，ラットを用いた繁殖 性およびラットおよびウサギを用いた催奇形性試験では，

影響および催奇形性は認められなかった。細菌を用いた復 帰変異原試験，DNA 修復試験および培视細胞を用いた染 色体異常試験では，いずれにおいても変異原性は陰性で あった ${ }^{18)}$.

エトキサゾール原体は，コイ等の魚類に対する毒性は低 いが，ミジンコなどの水棲節足動物には影響を及ぼす可能 性がある、マガモおよびウズうを用いた試験から鳥類に対 する影響はないと考えられた。また，ミツバ千，ミミズお よび緑藻類に対しても通常の使用では影響はないと考えら れた。力イコには強い影響が認められた ${ }^{199}$.

\section{2. 植物および土壤中における代謝分解}

植物および土壤中でのエトキサゾールの動態を検討する ために，2 種類の ${ }^{14} \mathrm{C}$-標識エトキサゾール(フェニル標識体 およびオキサゾール標識体)を用いて代謝分解試験を行っ た.

なす，りんごおよびオレンジに対して ${ }^{14} \mathrm{C}$-標識エトキサ ゾールのフロアブル製剂を慣行施用量で散布し，経時的 に ${ }^{14} \mathrm{C}$-標識エトキサゾール並びにその代謝物を分析した。 その結果，果実および葉の表面から植物体内への浸透移行 は低く，3作物のいずれにおいても検出された代謝物の種 類並びに量は，基本的に同じであった。りんごの場合では， 屋外栽培のりんごの木に $0.15 \mathrm{~kg}$ a.i. $/ \mathrm{ha}$ 相当の ${ }^{14} \mathrm{C}$-標識工 トキサゾールを散布し，0，14，21，30 日後に果実と葉を採 取してそれぞれを分析した，収穫期の果奏と葉において， 放射活性の総残留量（TRR）の約 $60 \%$ 表面洗浄液に回収 され，浸透性が低いことが示唆された。また，収穫期の果

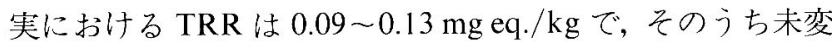
化体が 41.1〜 42.3\%，主たる代謝物であるジベンズアミド $\mathbf{R 3}$ およ゙アミノエステル R7が，それぞれ 3.3〜4.6\%およ U゙7.5〜8.8\%, 抽出残渣が 23.1〜23.5\%であった. 果実㧍よび 葉の表面や組織中でエトキサゾールは，先ず，加水分解に よって1,3-オキサゾリン環の開裂によるアミノエステル R7 および酸化によるオキサゾール R13 となり，引き続く 加水分解および酸化によって速やかに分解され，抱合体お よび結合残留物に代謝分解されると推定された（Fig. 5).

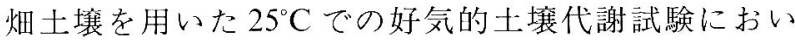
て，エトキサゾールの半減期は 18.6 日，90\%消失期が約 62 日であった。359日間では，主に微生物によって施用量の 20 61\%が ${ }^{14} \mathrm{CO}_{2}$ にまで無機化され, 17〜 40\%の抽出残渣 は, 主にフミンおよび腐植酸画分に分布した.土塞中からア

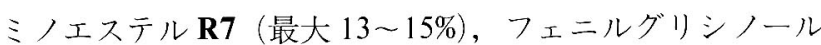
R8（最大 16\%) およびオキサゾール R13（最大 13～14\%) 


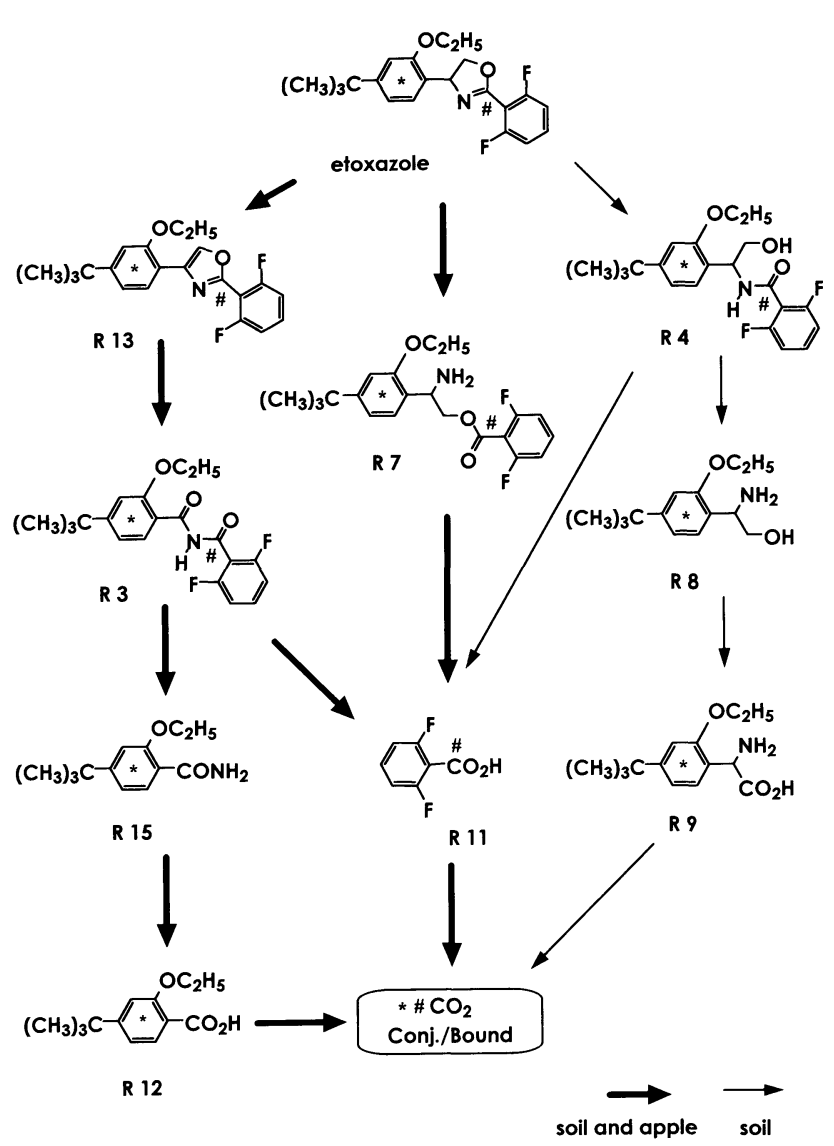

Fig. 5 Proposed biotransformation pathway of etoxazole in apple and soil.

の 3 種類の主要代謝物が検出された。エトキサゾールは, Fig. 5 に示す代謝経路によって, 加水分解および酸化によ り急速に代謝分解されると推察された。

$$
\text { おわりに }
$$

エトキサゾールは，植物寄生性のハダニ類に対して極め て低濃度で殺卵, 殺幼若虫活性を示す殺ダ二剂である. 従 来の殺ダ二剂との作用性の相違を十分に解明できていない が，哺乳動物に対する毒性は低く，使用場面などから有用 生物に対する影響は少ないと思われる，また，環境中では 速やかに分解されるため, 環境負荷の少ない農薬であり， 日本を始め，世界各国においてハダ二類防除に貢献できる ものと考えている.

エトキサゾールは，1990 年に殺ダニ剂として開発するこ とを決意し，1998 年に登録・上市することができたが，こ の間, 安全性評価試験，工業化等に絶大な示唆・ご指導・ ご協力を頂いた（財）残留農薬研究所, 住友化学工業株式 会社および大日本インキ化学工業株式会社, また, 生物評 価試験にご指導を頂いた日本植物防疫協会, 各試験・研究 機関並びに全国農業協同組合連合会に禹心より感謝申し上 げます。

\section{引用 文 献}

1）山田富夫・帰山＼cjkstart稔·松井宣夫・米田 渥：農薬誌 12, 327335 (1987)

2) SHIBUYA INDEX - 1999- (8th Edition), SHIBUYA INDEX 研究会発行

3)「新農薬の展望」, 井倉勝弥太監修, シーエムシー

4) K. Yagi, K. Akimoto, N. Mimori, T. Miyake, M. Kudo, K. Arai \& S. Ishii : Pest. Manag. Sci. 56, 65-76 (2000)

5) T. Takemoto \& T. Nakajima : J. Pharm. Soc. Jpn. 84, 1183 (1964)

6) T. Takemoto, T. Yokobe \& T. Nakajima: J. Pharm. Soc. Jpn. 84, 1186 (1964)

7) M. Onda, H. Fukushima \& M. Akagawa: Chem. Pharm. Bull. 12, 751 (1964)

8) F. G. F. Eloy, R. St. Genese \& R. A. V. Lenaers (Mallinckrodt Chemical Works) : U.S. US 3574222 (1971)

9) D. G. Kuhn (American Cyanamide Co.) : U.S. US 4659857 (1987)

10) 作田庄平：農化 69, 147 (1995)

11) K. R. Jennings, D. G. Kuhn, C. F. Kukel, S. H. Trotto \& W. K. Whitney : Pest. Biochem. Physiol. 30, 190-197 (1988)

12) K. Toda, M. Goto, Y. Kikuchi, R. Mori, Y. Takeuchi, T. Takematsu \& A. Suzuki : J. Pesticide Sci. 13, 19-27 (1988)

13）佐藤義弘・小磯彰宏・朝田 亨. 三浦康尚（大日本インキ 化学)：特開平 6-135916 (1994)

14）佐藤義弘・小磯彰宏・朝田 亨 - 三浦康尚・菊池靖夫・針 谷康明 (大日本インキ化学, 八洲化学)：特開平 6-135917 (1994)

15) T. Ishida, J. Suzuki, Y. Tsukidate \& Y. Mori : Proc. Brigton Crop Prot. Conf. Pests and Diseases, 1, 37-44 (1994)

16) 丹治功男-月舘洋吉- 森川千晴：第 40 回日本応用動物昆虫 学会大会講演要旨, p.90, 1996

17) 浜 弘司：植物防疫 44，394-397 (1990)

18) 八洲化学：農薬誌 25, 463-467 (2000)

19）渋谷一郎：農薬時報（臨時増刊), No.16, 2-5 (1998) 


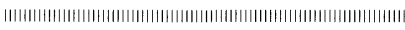

Society Awards 2001

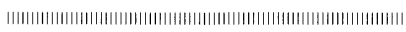

(on prominent achievement)

\section{Development of a New Acaricide, Etoxazole}

\section{INTRODUCTION}

Etoxazole, a derivative of 2,4-diphenyl-1,3-oxazoline is a novel acaricide discovered by Yashima Chemical Industry. The idea of this compound basically came from the moiety of bioactive natural products and wellknown pesticides. But etoxazole is the first acaricide to employ a 1,3-oxazoline moiety as a pesticide. The mode of action of this compound has not been determined yet, however, it may act on the molting process of mites and has no cross resistance with conventional acaricides.

Five-membered heterocyclic structures having oxygen and nitrogen atoms are widely found in bioactive natural products. Tricholomic acid and ibotenic acid which were isolated from mushrooms are isoxazole derivatives and show insecticidal activity against houseflies (Musca domesticae). ${ }^{1-3)}$ Regarding artificial compounds, heterocyclic compounds such as 1,2,4-oxadiazole and 1, 3-oxazol-5-one with substituted phenyl groups exhibit insecticidal and acaricidal activities. ${ }^{4,5}$ Perhaps it is a good way to develop new pesticides using heterocyclic structures as described above.

On the other hand, it is very easy for mites to develop their resistance against conventional acaricides as their lives are shorter than usual pesticides. So new acaricides having a unique structure and a different mode of action than existing acaricides are required in the agricultural market.

"BAROQUE FLOWABLE" as the commercial name of etoxazole was registered and launched in Japan in April 1998.

\section{LEAD COMPOUND AND ETOXAZOLE}

We have found that substituted phenylacetic acid anilides showed insecticidal activities against houseflies and diamondback moths during the course of our research to find a new herbicide in the middle of the 1980s. Although we synthesized and tested various compounds to enhance these activities, we could not obtain good results. On the other hand, compounds having a five-membered heterocyclic structure and substituted benzene ring were considered to be a potent insecticide from patents and literature. 4-Benzyl-2pheny-1,3-oxazoline was synthesized based on the above idea and showed ovicidal and insecticidal activities against Tetranychus urticae and Plutella xylostella. After an examination to enhance these activities for various compounds, we found that substituted 2,4diphenyl-1,3-oxazolines exhibited a strong activity against eggs, larvae and nymphs of $T$. urticae and the extent of activity varied with substituents on two benzene rings.

The compound which fluorine and chlorine atoms substituted at both ortho positions on the 2-phenyl group, showed the strongest ovicidal activity $\left(\mathrm{LC}_{50}\right.$ : $0.01-0.1 \mathrm{ppm})$. The compound that two fluorine atoms attached to both ortho positions on the 2-phenyl group has excellent ovicidal and larvicidal activities against $T$. urticae and Myzus persicae.

Introduction of hydrophobic bulky substituents to the para position on the 4-phenyl group enhanced the activities against these insects. But hydrophilic subtituents such as hydroxy and dimethylamino groups decreased the activities. Additional substituents, such as methoxy, ethoxy and butoxy groups, to the ortho position on the 4-phenyl group were favorable for the ovicidal and the insecticidal activities. We used Tetranychus kanzawaii and Panonychus citri instead of T. urticae to check the efficacy of high activity compounds in order to select a developing compound. These mites showed a low sensitivity towards conventional acaricides such as hexythiazox. This may be the best way to choose a compound that will not have the cross-resistance problem.

On the other hand the acaricidal activity of 1,3oxazoline derivatives was stronger than those of 1,3oxazole and 1,3-thiazoline derivatives. The substitution of two phenyl groups at 2- and 4- position on the 1, 3 -oxazoline ring was more favorable than 2 - and 5position.

Etoxazole was chosen for the most effective acaricide according to our studies in November of 1990.

\section{SYNTHESIS}

Synthetic route of etoxazole is shown in Fig. 2. N[1-(4-tert-butyl-2-ethoxyphenyl)-2-chloroethyl]-2,6difluorobenzamide (chloroamide) was synthesized from 3-tert-butylphenetol(MTBPE) and N-(2-chloro-1methoxyethyl)-2,6-difluorobenzamide(amidacetal) by the Friedel-Crafts reaction using $\mathrm{AlCl}_{3}$. Amidacetal was prepared from 2,6-difluorobenzamide and chloroacetaldehyde dimethyl acetal in the presence of Lewis acids. ${ }^{6)}$ Etoxazole was synthesized by cyclization of chloroamide with $\mathrm{NaOH}$ in good yields. ${ }^{\text {) }}$ 


\section{BIOLOGICAL PROPERTIES}

Etoxazole has a high activity on eggs, larvae, protonymphs and deutonymphs of various mites, but no activity against adult mites. The $\mathrm{LC}_{50}$ values of ovicidal activity against four major mites such as T.urticae, $T$. kanzawai, $P$. citri and $P$. ulmi were $0.001-0.005 \mathrm{ppm}$ using the leaf-disc dipping method, which were 100 times lower dosage level than hexythiazox. A mode of action of etoxazole appears to be an inhibition of the molting process of mite similar to hexythiazox from the microscopic observation, but etoxazole is active for control of hexythiazox-resistant mites such as $T$. kanzawai and $P$. citri.

Etoxazole also shows good effects on the juvenile stage of aphids and makes the molting process incomplete in a similar manner with mites. This effect is unique since recent acaricides having the similar molting inhibition activity to mites provide no control of aphids.

In field trials etoxazole has a long-lasting efficacy with a very low application rate and no crop injury. When etoxazole was applied for $T$. urticae on apples with the concentration of $50 \mathrm{ppm}$ in field trial, the number of mites was suppressed over a month.

\section{SAFETY}

The results of studies in labolatry animals reveal that etoxazole has low acute mammalian toxicity following oral, dermal and inhalation exposure. No critical irritant effects on eye and skin were noted. From subchronic and long-term toxicology studies, it can be derived that the toxicity of etoxazole is rather low. There were no signs of oncogenic responses in any of the tested animals. No adverse effects were noted on reproductivity and no signs of teratogenic effects were noted. No effects were noted in a battery of mutagenicity studies conducted. Based on the review of the studies summarized above, the Japan Ministry of Health and Welfare established an Acceptable Daily Intake(ADI) for etoxazole as $0.004 \mathrm{mg} / \mathrm{kg} /$ day.

Toxicities to avian, aquatic organisms and non target organisms were low except aquatic arthropods and silkworms.

Etoxazole poses a very low risk for the user under normal agronomic condition.

\section{PLANT AND SOIL METABOLISM}

Metabolic studies of etoxazole were examined using two types of ${ }^{14} \mathrm{C}$-labeled compounds. Plant metabolism was studied using eggplants, apples and oranges. ${ }^{14} \mathrm{C}$ etoxazole, which applied on fruits and leaves, almost remained on their surface, and did not transport into their inner tissues. Quantity and kinds of detectable metabolites were basically the same in three plants. Unchanged etoxazole, dibenzamide( $\mathbf{R 3})$, aminoester $(\mathbf{R} 7)$ and oxazole(R13) were detected as main metabolites in harvested apples. A proposed metabolic pathway was shown in Fig. 5.

Half lives of ${ }^{14} \mathrm{C}$-etoxazole in apple orchard soil under an aerobic condition at $25^{\circ} \mathrm{C}$ was 18.6 days for both labeled forms. Ninety percents of the applied ${ }^{14} \mathrm{C}$ etoxazole disappeared within 62 days and $20-61 \%$ of them were degraded up to $\mathrm{CO}_{2}$ by mainly microorganisms during 359 days. Three major metabolites were detected in the soil and the degradation pathway was estimated as shown in Fig. 5.

\section{REFERENCES}

1) T. Takemoto \& T. Nakajima : J. Pharm. Soc. Jpn. 84, 1183 (1964)

2) T. Takemoto, T. Yokobe \& T. Nakajima: J. Pharm. Soc. Jpn. 84, 1186 (1964)

3) M. Onda, H. Fukushima \& M. Akagawa: Chem. Pharm. Bull. 12, 751 (1964)

4) F. G. F. Eloy, R. St. Genese \& R. A. V. Lenaers (Mallinckrodt Chemical Works) : U.S. US 3574222 (1971)

5) D. G. Kuhn (American Cyanamide Co.) : U.S. US 4659857 (1987)

6) Y. Sato, A. Koiso, T. Asada \& Y. Miura (Dainippon Ink Chem.) : Jpn. Kokai Tokkyo Koho, JP 06-135916 (1994)

7) Y. Sato, A. Koiso, T. Asada, Y. Miura, Y. Kikuchi \& Y. Hariya (Dainippon Ink Chem. \& Yashima Chem.) : Jpn. Kokai Tokkyo Koho, JP 06-135916 (1994) 